\title{
An unusual cause of gross abdominal distension in a 59-year-old man: huge mesenteric cyst
}

\author{
William Reginald Joseph Carr, I Bain
}

Department of Colorectal Surgery, University Hospital Of North Durham, Durham, UK

Correspondence to Mr William Reginald Joseph Carr, wrjcarr@doctors.org.uk

\section{DESCRIPTION}

A 59-year-old man presented to the emergency team with abdominal pain and gross abdominal distension. His history was unremarkable with no previous liver disease or alcohol excess. Clinical examination suggested gross ascites but no signs of liver disease. Abdominal x-ray suggested ascites (figure 1). Routine blood investigations were unremarkable. Clinically, the patient appeared to have large volume tense ascites with no obvious underlying cause. Before drainage, ultrasound and contrast CT scan of the abdomen were performed which revealed a massive $(37 \times 35 \times 21 \mathrm{~cm})$ clear fluid filled cyst extending from the xiphisternum to the symphysis, arising the large bowel mesentery and displacing the left kidney inferiorly as it extended in the retroperitoneum over the left adrenal gland (figures 2-4). We proceeded with a laparotomy through a midline incision. A large cyst was identified in the sigmoid mesentery with gross distortion of the normal anatomy

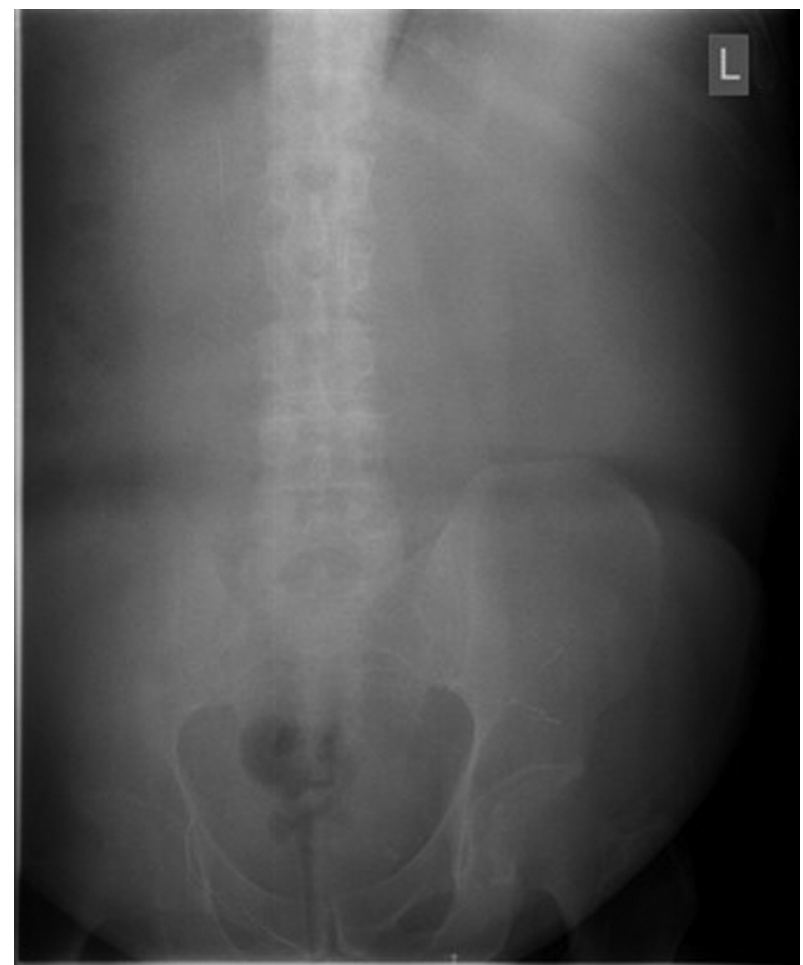

Figure 1 Abdominal x-ray showing absence of central bowel loops.

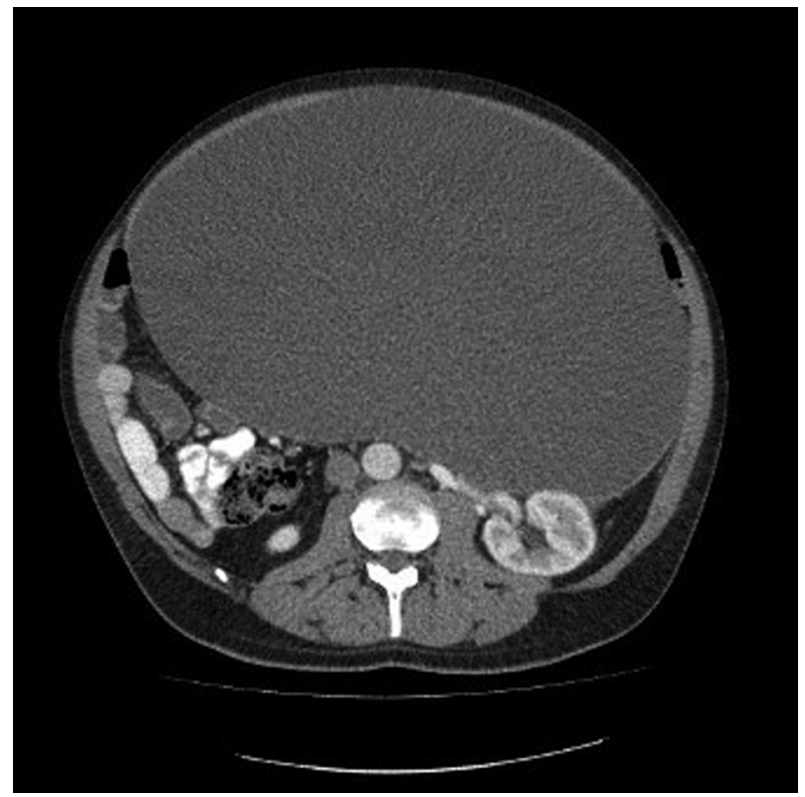

Figure 2 Axial CT slice showing huge mesenteric cyst with inferior displacement of the left kidney and below.

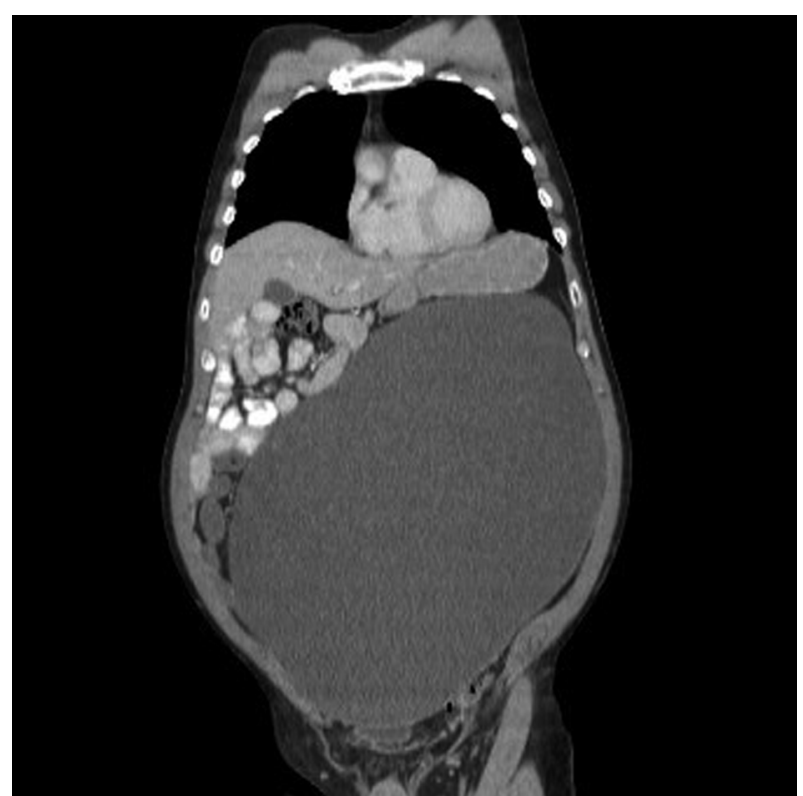

Figure 3 Coronal CT slice showing huge mesenteric cyst extending from the xiphisternum to the pubic symphysis. 


\section{BMJ Case Reports}

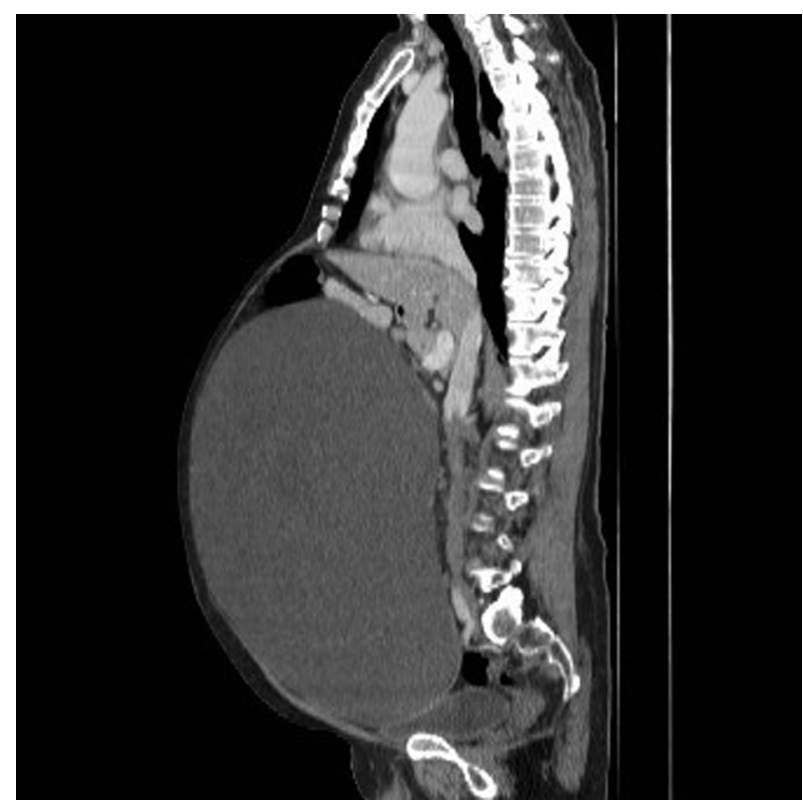

Figure 4 Sagittal CT slice showing huge mesenteric cyst.

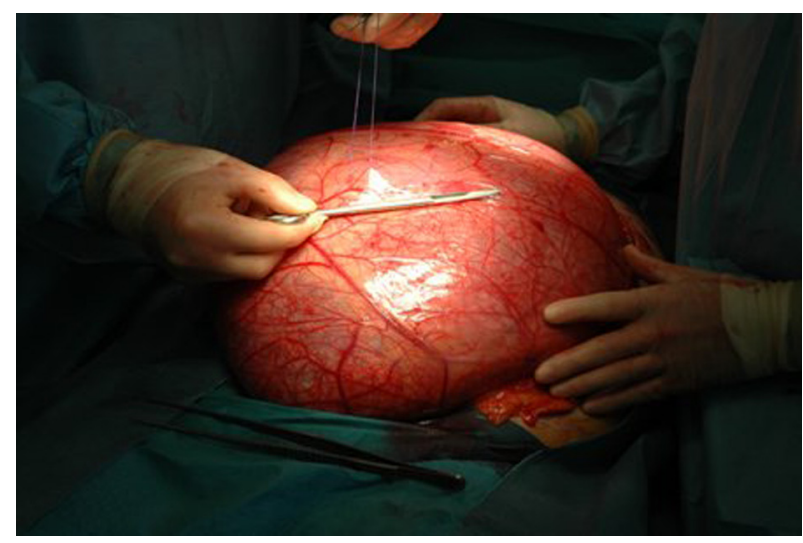

Figure 5 The appearance of the cyst at laparotomy.

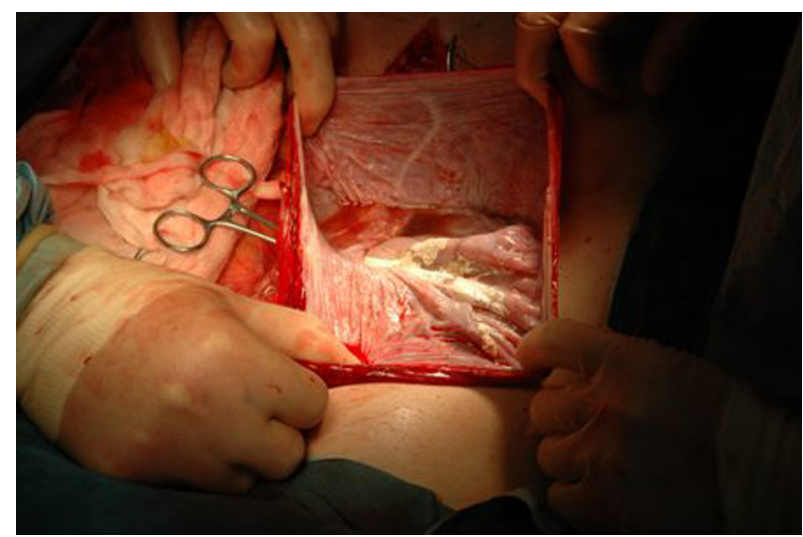

Figure 6 A view inside the cyst after drainage.

(figures 5-8). The inferior mesenteric vein was running over the cyst but was only identified after drainage of 18 litres of clear fluid. The cyst wall was excised from its

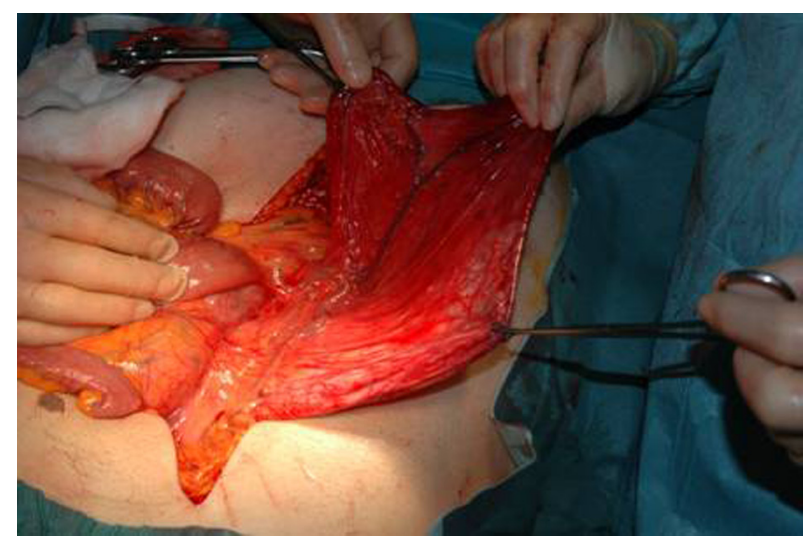

Figure 7 View of the deflated cyst wall lying in the mesentery of the colon.

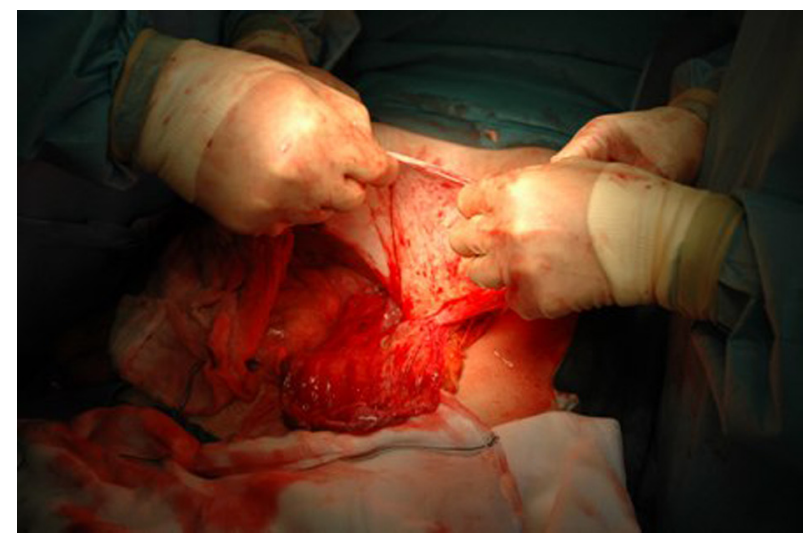

Figure 8 A demonstration of the plane developed between the cyst wall and the mesentery. This extended up to above the left kidney.

origin in the sigmoid mesentery and was carefully dissected free. Preservation of the colonic blood supply and ureters was achieved. Histological examination revealed a benign simple true cyst, with patchy mural calcification. Fluid cytology revealed occasional macrophages with no epithelial component. Biochemistry revealed an albumin level of $27 \mathrm{~g} / \mathrm{l}$. Postoperatively, he made an excellent, uncomplicated recovery and was discharged 4 days postoperatively. Appropriate imaging made the diagnosis which was not possible clinically and informed the surgeon of the structures likely to be encountered.

\section{Learning points}

- A high index of clinical suspicion allied with appropriate imaging is necessary to fully investigate rare causes of abdominal distension.

- Careful surgical excision in the presence of distorted anatomy is necessary to avoid significant visceral or vascular injury.

Competing interests None.

Patient consent Obtained. 


\section{BMJ Case Reports}

This pdf has been created automatically from the final edited text and images.

Copyright 2012 BMJ Publishing Group. All rights reserved. For permission to reuse any of this content visit http://group.bmj.com/group/rights-licensing/permissions.

BMJ Case Report Fellows may re-use this article for personal use and teaching without any further permission.

Please cite this article as follows (you will need to access the article online to obtain the date of publication).

Carr WRJ, Bain I. An unusual cause of gross abdominal distension in a 59-year-old man: huge mesenteric cyst . BMJ Case Reports 2012;10.1136/bcr.02.2012.5812, Published XXX

Become a Fellow of BMJ Case Reports today and you can:

- Submit as many cases as you like

- Enjoy fast sympathetic peer review and rapid publication of accepted articles

- Access all the published articles

- Re-use any of the published material for personal use and teaching without further permission

For information on Institutional Fellowships contact consortiasales@bmjgroup.com

Visit casereports.bmj.com for more articles like this and to become a Fellow

Keep up to date with all published cases by signing up for an alert (all we need is your email address) http://casereports.bmj.com/cgi/alerts/etoc 